\title{
Capital Outflows and Unemployment: A Panel Analysis of OECD Countries
}

\author{
Burçak Polat ${ }^{1}$ \\ ${ }^{1}$ Department of Economics, Nuh Naci Yazgan University, Kocasinan/ Kayseri, Turkey. \\ Correspondence: Burçak Polat, Department of Economics, Nuh Naci Yazgan University, Kocasinan/ Kayseri, Turkey
}

Received: June 27, 2016

Accepted: July 14, 2016

Available online: July 8, 2016

doi:10.11114/aef.v3i4.1748

URL: http://dx.doi.org/10.11114/aef.v3i4.1748

\begin{abstract}
Liberalization of trade and payment regimes after the mid-1980s expedited capital outflows, especially from developing countries toward developed ones. This inevitable trend has given rise to new discussions among scholars regarding the real effect of capital movements abroad on the domestic labor market. However, the debate is ambiguous and ongoing. Thus, the main objective of this study is to determine the relationship between capital outflows and employment levels in the home country from 2006-2013 in 30 Organization for Economic Co-operation and Development (OECD) countries. We have employed dynamic panel data methods to capture the causal relationship between capital outflows and employment levels. Finally, our empirical predictions show that capital outflows lead to a reduction in employment levels in the home market, whereas a larger market size leads to an increase in the employment levels.
\end{abstract}

Keywords: Unemployment rate, Capital outflows, FDI outflows, Dynamic Panel Data

JEL Codes: C23, F21, F23, F24, F29

\section{Introduction}

Liberalization of capital accounts, following implementation of the new export-oriented policies by many developing countries after the mid-1980s, expedited capital outflows, especially from developing countries toward developed ones. This inevitable trend has given rise to new discussions among scholars regarding the real effect of capital movements abroad on the domestic labor market. However, the debate is ongoing and unclear.

There are two main types of capital outflow: foreign direct investments (FDIs) and portfolio investments (PIs). FDIs as investment vehicles promising long-term commitments are the first to come to mind and may have a strong influence on the employment levels, both at home and in the host market. However, PIs are short-term commitments and emerge as a reaction to sudden shocks (such as interest rate differentials) in the international market. Thus, the expected effect of PIs on the employment levels may be minimal or temporary. Accordingly, this study will deal with the relationship between FDI outflows and the unemployment levels in the home market; capital outflows will refer to FDI outflows in the remainder of this work.

Regarding the real effect of FDI outflows on home labor markets, there are two opposing views where scholars depart from one another. On one side, they argue that FDIs may deter employment in the home market. Since FDI outflows reduce the supply of capital goods to invest at home, this will likely reduce domestic investments and, in turn, decrease local firms' demand for labor. Hence, supporters of this view claim that FDI outflows have a negative impact on home employment and may lead to the layoff of existing workers in the job market. Others argue the opposite point of view. They believe that multinational firms investing overseas need to be more competitive in order to gain a greater international market share. Thus, corporate leaders need to hire more labor in the home country for research and development (R\&D) activities, and they must ensure that their supervision is innovative and that they remain highly competitive with their rivals. In addition, they argue that outward FDIs may also have a positive effect on the levels of employment in the home country.

The main objective of this study is to determine the relationship between FDIs and home labor market employment. The study covers 30 OECD countries from 2006 to 2013. The contribution of the study is as follows: First, the study employs the one-step system generalized method of moments (GMM) of panel data to capture the endogeneity between FDIs and unemployment. Second, with the appropriate data and methodology, the study is able to prove if FDIs are 
beneficial to the local labor market or not. Third, the study is able to determine if the world economic crisis which arose at the end of 2007 had a deterrent effect on the employment levels or not.

The remainder of the paper is organized as follows: The second section examines previous studies dealing with the impact of FDIs on employment in the home market. This is followed by the third section which describes the data and the methodology utilized in this work and explains the empirical results based on economic theory. The last section concludes the study with a discussion and offers insights on the study's implications.

\section{Literature Review}

The effects of FDI outflows on home countries have been studied to determine the extent to which expansion of production by multinational firms reduces the demand for labor in the home market. However, the impact of allocating production overseas on the levels of home country employment is vague and controversial.

Some argue that the allocation of multinational firm (MNF) resources to more productive foreign markets will prevent domestic firms from developing new jobs and will, in fact, reduce employment levels. Stevens and Lipsey (1992) claimed that capital outflows and employment levels at home are not independent of each other, and that an increase in plant and equipment investments in foreign operations will increase the cost of capital in the home market and increase the unemployment levels. Furthermore, Eckel (2003) explained the negative linkage between home country demand for labor and outward investments in a neoclassical trade model. He argued that exporting capital overseas will reduce the supply of capital goods in the home market and lead firms to downscale their operations. The negative impact of capital outflows on domestic employment has been supported by Frank and Freeman (1978), Brecher and Choudhri (1978), Glicman and Woodward (1989), Blomstrom, Fors, and Lipsey (1997), and Basu (1998), as well.

Blomstrom et al.'s study (1997) investigated the relationship between foreign affiliate production and parent company employment in the U.S. and Sweden. They noted that MNFs prefer to shift their labor intensive operations to foreign markets where labor costs are relatively cheaper. Thus, deterring the effect of capital outflows may depend on the development levels in both the home and host countries. FDI outflows from developed countries (such as the U.S. where the labor costs are high) to developing countries (where labor costs are lower) will cause a reduction in the levels of employment in the home market.

However, some argue that FDI outflows may promote the employment levels in the home market. Lipsey's study (1994) found that MNFs with higher shares of production overseas have higher employment at home. The reason is that firms engaged in foreign investment activities have to hire more employees in the home market to perform $R \& D$ and supervisory functions to be competitive. Blomstrom et al. (1997) also argued that, unlike U.S. firms, Swedish firms distribute capital to developed countries so that FDI outflows will produce more employment as unskilled jobs are preserved in the home market. Moreover, Lin and Wang (2008) examined the relationship between capital outflows and unemployment rate in the home country and found that FDI outflows are beneficial to employment in the home market. In an opposing argument, Chen and $\mathrm{Ku}$ (2000) did not find evidence of any relationship between capital outflows and employment levels in the home country.

\section{Data and Methodology}

\subsection{Data}

While the unemployment rates in 30 OECD countries has been selected as our dependent variable, outward FDIs that account for capital outflows has been determined to be the main explanatory variable of interest. Furthermore, gross domestic product (GDP), inflation, and country risk (CR) index are taken into consideration in the model as the most important control variables to ensure the robustness of the results. We also incorporate time dummies to capture the effect of the 2007 world crisis, if any, on employment levels. Unemployment rate, GDP, and inflation information have been obtained from the World Bank Data dissemination tool (www.data.worldbank.org). Here, the CR index is a composite index of the economic, financial, and political risks of each home country. In other words, the CR index represents risk ratings that measure the economic, political, and financial strengths of the home country. Data on the CR index have been taken from the Political Risk Services data retrieval tool (www.prsgroup.com). An important note regarding the CR index is that data points range from very high (0-49) to very low (50-80), which means that, as the points increase, the risks decrease. Both dependent and explanatory variables are measured in U.S. dollars.

Descriptive statistics on all data in the analysis and their expected effect on the employment levels are presented on Table 1. 
Table 1. Descriptive Statistics and Expected Sign of the Coefficients

\begin{tabular}{lcccccc}
\hline Variables & Sign & Observations & Mean & Std. Deviation & Minimum & Maximum \\
\hline Unemployment (\%) & - & 228 & 7.241 & 3.473 & 2.5 & 27.2 \\
FDI outflows & $(+-)$ & 228 & 65.689 & 113.77 & -48.397 & 596.51 \\
GDP & $(+)$ & 228 & 146.75 & 287.45 & 1.695 & 1676.80 \\
Inflation (\%) & $(-)$ & 228 & 1.978 & 2.157 & -5.204 & 11.347 \\
CR index & $(+)$ & 228 & 77.73 & 6.800 & 56.62 & 92 \\
Openness & $(+)$ & 228 & 101.13 & 61.76 & 24.76 & 371.43 \\
\hline
\end{tabular}

As seen in Table 1, there are no missing values in the observations. The most volatile variables are GDP and FDI outflows with high values of standard deviation $(S D)$. As one may assume, foreign investors may invest abroad due to inefficient demand for their products and services in the home market. Thus, a possible explanation for variations in FDI outflows is that, even though countries in the analysis have similar CR ratings, variations in GDP may lead to variations in FDI outflows, as well. Countries with low market potential (low GDP) relative to countries with a high market potential may find it preferable to invest abroad. Furthermore, since we integrate the net FDI outflows, rather than nominal ones, as an indicator of capital outflows, minimum and maximum values of capital outflows show that FDI outflows may become a negative value as FDI inflows are realized in the home country.

\subsection{Methodology}

Panel data analysis is used to allow for the unobserved time invariant variable to be correlated with the dependent variable and explanatory variables. However, ordinary least squares (OLS) produces biased results of estimators under panel data analysis. Therefore, one needs to correct for correlation between individual effects and explanatory variables. There are two important panel data models that solve the collinearity problem among individual effects and independent variables. These are the random effects (RE) and fixed effects (FE) models. While the FE model eliminates the unobserved effect just by transformation, the RE model simply assumes that it is uncorrelated with each explanatory variable in all the periods.

However, many economic issues are dynamic by their very nature and use the dynamic panel data structure. The dynamic panel data allows for endogeneity between dependent variables and explanatory variables and enables the capture of causal relationships among variables. A general dynamic panel data equation can be formulated as follows:

$$
Y_{i t}=\delta Y_{i t-1}+X_{i t}^{\prime} \beta+u_{i t} \quad ; i=1,2,3, \ldots \ldots \ldots \ldots . . N, t=1,2 \ldots \ldots \ldots . . T
$$

$u_{i t}=e_{i}+v_{i t}$ where $e_{i}$ is usual unobserved fixed effects or individual effects distributed $i i d\left(0, \sigma_{e}^{2}\right)$, and $v_{i t}$ is the usual error term distributed $\operatorname{iid}\left(0, \sigma_{v}^{2}\right)$.

The problem of employing dynamic panel data arises because, while $Y_{i t}$ is correlated with $e_{i}, Y_{i, t-1}$ is also correlated with $e_{i}$. Thus, OLS is biased and inconsistent even if $v_{i t}$ is not serially correlated. Quasi-demeaning transformation of variables by the RE model does not work, since dynamic panel data nestle lagged of dependent variable $\left(Y_{i, t-1}\right)$, $\left(Y_{i, t-1}-\ell \bar{Y}_{i}\right)$ term will be still correlated with $\left(u_{i, t-1}-\ell \bar{u}_{i}\right)$ because $u_{i}$ contains $u_{i, t-1}$ which is correlated with $Y_{i, t-1}$. However, Arellano and Bond (1991) argued that there might be a GMM procedure that is both unbiased and efficient. The idea of this approach is that one should use the first difference to get rid of the individual effects and use all the past information of $Y_{i t}$ for instruments.

A dynamic panel model is specified with $i$ indexing countries and $t$ indexing time.

The basic specification is

$$
y_{i, t}=\alpha_{0 t}+\alpha y_{i, t-1}+\sum_{k=1}^{11} \delta_{k} X_{k i t}+\eta_{i}+\varepsilon_{i t}
$$

where $y_{i, t}$ stands for the unemployment rate in each home country, and the second term, $y_{i, t-1}$, following the time-varying $\alpha_{0 t}$ in the equation, is the lagged dependent variable. $X_{k}$ represents a set of macroeconomic variables and risk factors that affect the unemployment rate, while $\eta_{i}$ and $\varepsilon_{i}$ represent the host country effects and the error term, respectively.

This study employed one-step system GMM estimations proposed by Blundell and Bond (1998) to account for potential 
endogeneity. Arellano and Bond (1991) suggested using the lagged levels of the regressors as instruments. This is valid as long as the error term is serially uncorrelated and the lags of the explanatory variables are weakly exogenous. Arellano and Bover (1995) and Blundell and Bond (1998) showed that the Arellano and Bond estimator can perform poorly if the autoregressive parameters are too large, or if the explanatory variables are persistent. In this case, the lagged levels of the variables became weak instruments. To compensate, both papers proposed implementing additional moment conditions using lagged first differences (LFD) as instruments for the levels equation. Thus, when the orthogonality conditions for the first difference equation and for the levels equation are both valid, then the system GMM is preferred to the first difference GMM since it uses more information from the instruments. Moreover, the system GMM is more efficient, especially with weak instruments.

\section{Empirical Results}

To estimate the causal relationship between FDIs and the unemployment rates in 30 OECD countries for the period from 2006-2013, we carried out two types of one-step GMM estimations: system GMM and difference GMM. The results of one-step GMM estimations are reported in Table 2.

Table 2. Estimation Results

\begin{tabular}{|c|c|c|}
\hline Variable & System GMM & Difference GMM \\
\hline Constant & $\begin{array}{l}1.5468 \\
(0.855)\end{array}$ & $\begin{array}{l}0.7216 \\
(0.113)\end{array}$ \\
\hline \multirow{2}{*}{ Unemployment $_{\mathrm{t}-1}$} & 1.191 & $\begin{array}{l}(0.113) \\
0.4780\end{array}$ \\
\hline & $(0.000)^{* *}$ & $(0.065)$ \\
\hline \multirow[t]{2}{*}{ FDIO } & 0.0024 & -0.0006 \\
\hline & $(0.026)^{*}$ & $(0.578)$ \\
\hline \multirow[t]{2}{*}{ GDP } & -0.001 & -0.0066 \\
\hline & $(0.003)^{* *}$ & $(0.088)$ \\
\hline \multirow[t]{2}{*}{ Inflation } & -0.2571 & -0.2525 \\
\hline & $(0.274)$ & $(0.215)$ \\
\hline \multirow[t]{2}{*}{ CR index } & -0.0319 & -0.1847 \\
\hline & $(0.693)$ & $(0.006)^{* *}$ \\
\hline \multirow[t]{2}{*}{ Openness } & -0.0029 & -0.0118 \\
\hline & $(0.414)$ & $(0.700)$ \\
\hline \multirow[t]{2}{*}{$\mathrm{d} 8$} & 0.7581 & -0.1251 \\
\hline & $(0.009)^{* *}$ & $(0.598)$ \\
\hline \multirow[t]{2}{*}{ d9 } & 2.3946 & 0.7041 \\
\hline & $(0.004)^{* *}$ & $(0.282)$ \\
\hline \multirow[t]{2}{*}{$\mathrm{d} 10$} & 0.7700 & 0.6246 \\
\hline & $(0.235)$ & $(0.176)$ \\
\hline \multirow[t]{2}{*}{ d11 } & $(0.0004)^{* *}$ & 0.5667 \\
\hline & $(0.999)$ & $(0.170)$ \\
\hline \multirow[t]{2}{*}{$\mathrm{d} 12$} & 0.3888 & -0.2901 \\
\hline & $(0.721)$ & $(0.617)$ \\
\hline \multirow[t]{2}{*}{ d13 } & 0.1513 & 0.7216 \\
\hline & $(0.805)$ & $(0.113)$ \\
\hline \multirow[t]{2}{*}{ Wald chi-square test (14) } & 1082.40 & 234.99 \\
\hline & $(0.000)^{* *}$ & $(0.000)^{* *}$ \\
\hline \multirow[t]{2}{*}{ Arellando Bond AR (2) } & -1.42 & -1.28 \\
\hline & $(0.156)$ & $(0.201)$ \\
\hline \multirow[t]{2}{*}{ Hansen test } & 17.36 & 13.76 \\
\hline & $(0.066)$ & $(0.088)$ \\
\hline Number of instruments & 25 & 22 \\
\hline Number of observations & 199 & 170 \\
\hline
\end{tabular}

Note. $* *$ Denotes $1 \%$ significance levels, whereas $*$ denotes $5 \%$ significance levels. The probability values of the coefficients are in the parentheses.

As seen in Table 2, both the Hansen test and the Arellano Bond AR (2) test statistics reject the null hypothesis ensuring the robustness of estimation results and absence of any problem regarding the overidentification of instruments. However, the one-step system GMM and the difference GMM give different outcomes with respect to both the sign of the coefficients and the significance levels of the estimators. Since, the one-step difference GMM leads to a loss of information in the instruments, this study relies on the estimation results of the one-step system GMM.

According to the results of the one-step system GMM, employment levels in the home country may be explained by FDIs and GDP. In other words, unemployment rate is affected positively by capital outflows, but negatively by a higher GDP. Based on the empirical findings, this study supports the arguments of previous works claiming a positive relation between FDI outflows and unemployment rate. Therefore, the positive impact of FDI outflows on the unemployment rate can be explained as follows: The exportation of capital goods through foreign investment activities is likely to reduce the number of investments in the home market. Capital drain poses an obstacle to the firms' business expansion activities. As a result, firms may undergo a contraction in their operations and, thus, reduce their demand for labor, possibly causing them to lay off existing workers in the home country. On other hand, an increase in the GDP leads to a 
reduction in the unemployment rate. This result is not surprising since a greater GDP refers to a higher market size and may signal a greater domestic demand for goods and services produced by domestic firms. As the market size grows, firms may be induced to increase their production capacity and create a demand for additional workers in the job market.

Lastly, this study finds strong evidence that the world economic crisis which emerged at the end of 2007 had a deterrent effect on the levels of employment for 2008 and 2009.

\section{Summary and Concluding Remarks}

The inevitable trend in capital movements after the 1980s gave rise to new debates regarding the real effect of FDIs on the levels of employment in the home market. However, scholars do not agree on this issue, and the real influence is still undetermined.

Thus, the main objective of this study was to measure the relationship between outward FDI flows and employment levels in 30 OECD countries for the period from 2006-2013. To do so, we have employed the one-step system GMM to control for the causality between FDI outflows and unemployment.

In summary, this study confirms a positive relationship between FDI outflows and unemployment rate. Our empirical results prove that capital outflows worsen the employment levels in the domestic labor market. In other words, as the capital goods are exported, the firms' need for capital in order to expand their operations increases as well. Consequently, they are likely to stop hiring additional workers or, even worse, may fire existing workers already in the job market. Contrary to the capital outflows, higher market size (GDP) induces local firms to expand their operations, and this creates the need for additional workers to meet the market demand for increased goods and services.

\section{References}

Arellano, M., \& Bond, S. (1991). Some tests of specification for panel data: Monte Carlo evidence and an application to employment equations. The Review of Economic Studies, 58(2), 277-297.

Arellano, M., \& Bover, O. (1995). Another look at the instrumental variable estimation of error-components model. Journal of Econometrics, 68(1), 29-51.

Basu, B. (1998). Efficiency wages, unemployment and international factor movements. Journal of International Trade and Economic Development, 7(3), 317-338.

Bloomstrom, M., Fors, G., \& Lipsey, R. (1997). Foreign direct investment and employment: Home country experience in the United States and Sweden. Economic Journal, 107(445), 1787-1797.

Blundell, R., \& Bond, S. (1998). Initial conditions and moment restrictions in dynamic panel data models. Journal of Econometrics, 87(1), 115-143.

Brecher, R. A., \& Choudhri, E. U. (1987). International migration versus foreign investment in the presence of $\begin{array}{lllll}\text { unemployment. Journal of International } & \text { Economics, } & \text { 23(3), }\end{array}$ http://dx.doi.org/10.1016/0022-1996(87)90059-6.

Chen, T. J., \& Ku, Y. H. (2000). The effect of foreign direct investment on firm growth: The case of Taiwan's manufacturers. Japan and the World Economy, 12(2), 153-172. http://dx.doi.org/10/1016/S0922.

Eckel, C. (2003). Labor market adjustments to globalization: Unemployment versus relative wages,. North American Journal of Economics and Finance, 14(2), 173-188. http://dx.doi.org/10/1016/1062-9408(02)00117-1

Frank, R., \& Freeman, R. (1978). The distributional consequences of direct foreign investment. New York: Academic Press.

Glickman, N., \& Woodward, D. (1989) The new competitors: How foreign investors are changing the U.S. economy. New York: Basic Books.

Lin, M. Y., \& Wang, J. S. (2008). Capital outflows and unemployment: evidence from panel data. Applied Economics Letters, 15(14), 1135-1139. http://dx.doi.org/10.1080/ 13504850600993655

Lipsey, R. (1994). Outward direct investment and the U.S. economy, National Bureau of Economics Research Working Paper, 4691.

Stevens, G., \& Lipsey, R. E. (1992). Interactions between domestic and foreign investment. Journal of International Money and Finance, 11(1), 40-62.

\section{$(\mathrm{cc}) \overline{\mathrm{EY}}$}

This work is licensed under a Creative Commons Attribution 3.0 License. 